\title{
Sulfur dioxide-enhanced Phytotoxicity of Ozone to Watermelon
}

\author{
Gwendolyn Eason and Richard A. Reinert \\ Department of Plant Pathology, North Carolina State University, and Air Resources Research Consortium, \\ Agricultural Research Service, U.S. Department of Agriculture, Raleigh, NC 27695-7629
}

James E. Simon

Department of Horticulture, Purdue University, West Lafayette, IN 47907

\begin{abstract}
Additional index words. Citrullus lanatus, melon, air pollution
Abstract. Three watermelon [Citrullus lanatus (Thunb.) Matsum \& Nakai] cultivars with different ozone $\left(\mathrm{O}_{3}\right)$ sensitivities were grown in a charcoal-filtered greenhouse and exposed in continuous-stirred tank reactor chambers to five levels $(0$, $100,200,300$, or $\left.400 \mathrm{~nL} \cdot \mathrm{L}^{-1}\right)$ of sulfur dioxide $\left(\mathrm{SO}_{2}\right)$ in the presence $\left(80 \mathrm{~nL} \cdot \mathrm{L}^{-1}\right)$ or absence $\left(0 \mathrm{~nL} \cdot \mathrm{L}^{-1}\right)$ of ozone $\left(\mathrm{O}_{3}\right)$ for 4 hours/day, 5 days/week for 22 days. In the presence of $\mathrm{O}_{3}, \mathrm{SO}_{2}$ increased foliar injury in all three cultivars, but the impact was greatest for the most $\mathrm{O}_{3}$-sensitive cultivar, 'Sugar Baby,' moderate for 'Crimson Sweet,' and least for the least $\mathrm{O}_{3}$ sensitive cultivar, 'Charleston Gray.' For all cultivars, $\mathrm{SO}_{2}$ intensified $\mathrm{O}_{3}$ suppression of leaf area for the first seven mainstem leaves and of dry weights for aboveground and total plant tissues. Root dry weight was independently suppressed by both pollutants, and the root : top ratio was linearly suppressed by $\mathrm{SO}_{2}$ alone. Sulfur dioxide combined with $\mathrm{O}_{3}$ can be detrimental to crop species such as watermelon. Thus, the potential for $\mathrm{SO}_{2}$ phytotoxicity should not be summarily dismissed, especially in the vicinity of $\mathrm{SO}_{2}$ point sources where $\mathrm{O}_{3}$ co-occurs.
\end{abstract}

Recent air-quality research in the United States has often focused on ozone $\left(\mathrm{O}_{3}\right)$, because it occurs over large areas and causes economically significant crop yield suppression (Heck et al., 1990). Sulfur dioxide $\left(\mathrm{SO}_{2}\right)$, a by-product from the combustion of fossil fuels, is neither as prevalent nor as phytotoxic as $\mathrm{O}_{3}$ (Reinert, 1984). Under some conditions, $\mathrm{SO}_{2}$ can stimulate plant growth (Weigel et al., 1990), but deleterious effects of $\mathrm{SO}_{2}$ include foliar injury (Beckerson and Hofstra, 1979) and growth and yield suppression (Weigel et al., 1990). Sulfur dioxide can be more damaging combined with $\mathrm{O}_{3}$ (Reinert, 1984; Reinert et al., 1975), but some effects of the combination appear to be species specific (Beckerson and Hofstra, 1979; Reinert, 1984).

The impact of $\mathrm{O}_{3}$ on watermelon and muskmelon has been examined recently because of air-quality problems in the melonproducing regions of southwestern Indiana (Simon et al., 1986) and the Ebro Delta of Spain (Reinert et al., 1992). Ambient levels of $_{3}$ at both locations induced foliar injury in watermelon (Decoteau et al., 1986; Reinert et al., 1992; Snyder et al., 1991) and muskmelon (Simini et al., 1989; Snyder et al., 1988), but a wide range of cultivar sensitivities was identified for both crops (Decoteau et al., 1986; Simini et al., 1989). Open-top field chamber research (Snyder et al., 1988, 1991) demonstrated that $\mathrm{O}_{3}$ can also suppress growth and yield of watermelon and muskmelon. In the melonproducing region of southwestern Indiana, elevated ambient $\mathrm{SO}_{2}$ levels and $\mathrm{O}_{3}$ co-occur (Simon et al., 1986; Snyder et al., 1988). Because $\mathrm{SO}_{2}$ has occurred for many years in that area and has been shown to increase $\mathrm{O}_{3}$ injury in cucumber (Beckerson and Hofstra, 1979), another cucurbit, investigation of the impact of $\mathrm{SO}_{2}$ on melon crop response to $\mathrm{O}_{3}$ was needed (Decoteau et al., 1986;

\footnotetext{
Received for publication 28 June 1995. Accepted for publication 9 Feb. 1996. We appreciate the technical assistance of Jeff Barton, Tommy Gray, and Stephanie Horton and the statistical advice of Susan Spruill. The use of trade names or vendors does not imply endorsement by the USDA or the North Carolina Agricultural Research Service nor criticism of similar ones not mentioned. The cost of publishing this paper was defrayed in part by the payment of page charges. Under postal regulations, this paper therefore must be hereby marked advertisement solely to indicate this fact.
}

Simon et al., 1986; Snyder et al., 1988). Thus, the objective of this research was to determine the extent to which $\mathrm{O}_{3}$ phytotoxicity to watermelon could be altered by $\mathrm{SO}_{2}$.

\section{Materials and Methods}

Three watermelon (Citrullus lanatus) cultivars were selected to represent different relative sensitivities to $\mathrm{O}_{3}$ : 'Charleston Gray' ( $\mathrm{O}_{3}$-insensitive), 'Crimson Sweet' (intermediately $\mathrm{O}_{3}$-sensitive), and 'Sugar Baby' (extremely $\mathrm{O}_{3}$-sensitive) (Decoteau et al., 1986). For each cultivar, three seeds were planted on 3 Feb. 1987 and 5 Feb. 1988 in each of eighty $15-\mathrm{cm}$ plastic pots filled with an artificial peat-perlite-vermiculite medium (Metro Mix 220; GraceSierra Horticultural Products Co., Milpitas, Calif.). Pots were placed in a greenhouse supplied with charcoal-filtered (CF) air. Two weeks after seeding, plants were thinned to one per pot and allowed to acclimate for 5 days before assignment to blocks and treatments. Since 'Charleston Gray' seeds did not germinate well in 1987, that cultivar had fewer plants per experimental unit in 1987 than the other two cultivars.

Plants were watered daily with tap water. Daylength was extended to $12 \mathrm{~h}$ with supplemental lighting from metal halogen lamps (PAR $=250 \mu \mathrm{mol} \cdot \mathrm{m}^{-2} \cdot \mathrm{s}^{-1}$ at plant height). The first week after transplanting, plants were fertilized with a dilute fertilizer solution (2.5 g Peter's 20N-20P-20K/L water; Grace-Sierra). Thereafter, plants were fertilized weekly with a more concentrated fertilizer solution ( $5 \mathrm{~g}$ Peter's $20 \mathrm{~N}-20 \mathrm{P}-20 \mathrm{~K} / \mathrm{L}$ water). Vines were attached to bamboo stakes to facilitate transport to and from exposure chambers and to maximize exposure of foliage to pollutants. When necessary, (2 methyl[1,1'-biphenyl]-3-yl) methyl 3(2-chloro-3,3,3-trifluoro-1-propenyl)-2,2-dimethylcyclopropane carboxylate (bifenthrin) was used at the manufacturer's recommended rate to control white flies and spider mites.

Exposures to $\mathrm{O}_{3}$ and $\mathrm{SO}_{2}$ were conducted in 10 continuousstirred tank reactor (CSTR) chambers (Heck et al., 1978) in a greenhouse bay supplied with CF air and adjoining the CF air growing bay. To expose two blocks of plants each day, the first block of plants was exposed in the morning and the second block 
of plants was exposed in the afternoon. Plants were returned to the $\mathrm{CF}$ air growing bay immediately after each exposure. Each block of plants was exposed for $4 \mathrm{~h}$ /day, 5 days/week for 22 days beginning 24 Feb. 1987 or 29 Feb. 1988. Ozone was generated by electrostatic discharge in compressed air (model GTC-1A; Griffin Technics Corp., Lodi, N.J.), and $\mathrm{SO}_{2}$ was supplied from a tank containing $1 \% \mathrm{SO}_{2}$ in dry nitrogen. Each gas was dispensed into CSTR chambers through rotometers (Heck et al., 1978). The concentrations of $\mathrm{O}_{3}$ and $\mathrm{SO}_{2}$ in each chamber were monitored by ultraviolet photometry (model 49; Thermo Electron Instruments, Hopkinton, Mass.) and flame photometry (model 8450; Monitor Labs, San Diego), respectively. Gas concentrations in CSTRs were sampled sequentially for 3-min intervals every $30 \mathrm{~min}$ by an automated time-shared monitoring system.

One day before the first exposure, the width of the first leaf (LFWIDTH) on each plant was measured at the widest point. Individual measurements ranged from 0.4 to $7.8 \mathrm{~cm}$ over the 2 years. We believed this measurement indicated vigor and/or size of the future plant and, thus, chose it as a potential covariate for postexperimental data analyses. Young leaves that have received only short periods of exposure to chronic doses of $\mathrm{O}_{3}$ and $\mathrm{SO}_{2}$ do not express visible foliar injury. Thus, only the first five mainstem leaves were sampled for visible injury on 15 Mar. 1987 or 22 Mar. 1988. The percentage of leaf area visibly injured was estimated for each of the five leaves, and the averages of these leaf ratings for each plant were used in data analyses. One day after the last exposure, plants were destructively harvested. Leaf area for the first seven leaves on the main stem was measured to include leaf tissue with and without visible injury. Roots from each plant were washed and bagged separately from the aboveground tissue (top). Tissues were dried at $60^{\circ} \mathrm{C}$ for $48 \mathrm{~h}$ and weighed. The total plant dry weight and the root : top dry weight ratio were calculated.

The treatment design for each experiment was a $2 \times 5 \times 3$ factorial with two $\mathrm{O}_{3}$ concentrations $\left(0\right.$ or $\left.100 \mathrm{~nL} \cdot \mathrm{L}^{-1} \mathrm{O}_{3}\right)$, five $\mathrm{SO}_{2}$ concentrations $\left(0,100,200,300\right.$, or $\left.400 \mathrm{~nL} \cdot \mathrm{L}^{-1} \mathrm{SO}_{2}\right)$, and three watermelon cultivars. The experimental design was a split plot with the 10 pollutant combinations serving as main-plot treatments and arranged in a randomized complete-block design with two blocks. The watermelon cultivars were the subplot treatments. Blocking was against plant size and exposure time: block one contained the larger plants that were exposed to pollutants in the mornings. The integrity of the blocks was maintained regardless of the greenhouse bay in which plants were located. Four containers of each cultivar (except for three containers of 'Charleston Gray' in 1987) were randomly placed in each chamber for a total of 220 and 240 plants in 1987 and 1988, respectively. The means for each cultivar within each CSTR were used for all statistical analyses.

To preserve the orthogonality of the split-plot design, the covariate, LFWIDTH, was split into two orthogonal parts, the sum of which equalled the centered original covariate (Pantula et al., 1989). The first term, designated as $\operatorname{cov}_{\mathrm{a}}$ and used to adjust the whole-plot error term (error) in each analysis by year, was calculated by subtracting the grand mean for the appropriate year from the whole-plot mean for LFWIDTH. The second term, designated $\operatorname{cov}_{b}$ and used to adjust the subplot error term (error ${ }_{b}$ ) in each analysis by year, was calculated by subtracting the whole-plot mean for LFWIDTH from the subplot mean for LFWIDTH. Analysis of variance (ANOVA) and analysis of covariance (ANCOVA) were conducted for each variable and experiment to determine the need for the covariate terms in residual plots. If the subplot error term was reduced in the ANCOVA compared to the ANOVA, then ANCOVA was used for residual plots.

Residual plots for each variable were examined for outliers, heterogeneous variances, and nonnormal data. Injury data were transformed by $\arcsin \left(\mathrm{Y}^{0.5}\right)$, but transformation was not necessary for any of the other variables. A separate analysis was conducted for each variable and each experiment, and Bartlett's chi-square test was used to determine whether or not variances were heterogeneous between years. Leaf area, transformed injury readings, and root, top, and total dry weights did not have homogeneous variances between the 2 years, so all combined-experiment analyses for these variables were weighted by the inverse of the appropriate mean square errors $\left(1 / \mathrm{s}^{2}\right)$ from the analyses by year.

After determining the need for weighting of variances, data for the 2 years were combined, with year considered to be a fixed factor. If neither covariate term was significant in the combined analysis of a variable, the covariates were deleted from all subsequent analyses. Consequently, ANCOVA was replaced with ANOVA for injury, leaf area, and root : top ratio data. The dose response of $\mathrm{SO}_{2}$ and all $\mathrm{SO}_{2}$ interactions were partitioned by orthogonal polynomial coefficients with contrast statements. Varietal trials indicated that the $\mathrm{O}_{3}$ response of 'Crimson Sweet' was more similar to 'Charleston Gray' than to 'Sugar Baby' (Decoteau et al, 1986). Therefore, hypotheses were developed to compare the response of 'Sugar Baby' to the average of the responses of 'Charleston Gray' and 'Crimson Sweet' and to compare the response of 'Charleston Gray' with that of 'Crimson Sweet.' In accordance with these hypotheses, cultivar effects (and cultivar $\times$ pollutant treatment interactions) were partitioned using orthogonal contrasts.

\section{Results}

Foliar injury was first visible 4 days after gas exposures began in 1987 on 'Sugar Baby' plants placed in chambers with the two highest $\mathrm{SO}_{2}$ concentrations combined with $\mathrm{O}_{3}$. In 1988, foliar injury was not obvious until 10 days after exposures began, and injury was then visible on 'Sugar Baby' plants exposed to 200, 300, or $400 \mathrm{~nL} \cdot \mathrm{L}^{-1} \mathrm{SO}_{2}$ combined with $\mathrm{O}_{3}$ and on 'Crimson Sweet' plants exposed to $300 \mathrm{~nL} \cdot \mathrm{L}^{-1} \mathrm{SO}_{2}$ combined with $\mathrm{O}_{3}$. All visible injury resembled $\mathrm{O}_{3}$ injury as described by Decoteau et al. (1986), and no visible injury occurred in either year on plants that were not exposed to $\mathrm{O}_{3}$. Although foliar injury occurred earlier and tended to be greater (leaf area affected and symptom severity) in 1987 than in 1988, the difference between years was not significant, and treatment effects on injury did not depend on year (Table 1). The intensity of foliar injury was significantly affected by $\mathrm{O}_{3}$ and $\mathrm{SO}_{2}$ concentrations and by cultivar, but the main effects of these factors were all interdependent. As expected, 'Sugar Baby' exhibited more $\mathrm{O}_{3}$ injury than the less $\mathrm{O}_{3}$-sensitive cultivars, and 'Charleston Gray' had less $\mathrm{O}_{3}$ injury than 'Crimson Sweet.' The foliar injury caused by $\mathrm{O}_{3}$ was increased in the presence of $\mathrm{SO}_{2}$ for all three cultivars, but the $\mathrm{SO}_{2}$ enhancement of $\mathrm{O}_{3}$ injury was greatest for 'Sugar Baby' (Fig. 1).

Total area of the first seven mainstem leaves was not affected by year or by a year $\times$ gas interaction (Table 1 ). Leaf area was suppressed by $\mathrm{O}_{3}$ and $\mathrm{SO}_{2}$, and the interaction of the pollutants was significant. In the absence of $\mathrm{O}_{3}$, the linear suppression of leaf area by $\mathrm{SO}_{2}$ was minimal, but the suppression of leaf area by $\mathrm{O}_{3}$ increased linearly with $\mathrm{SO}_{2}$ concentration (Fig. 2). As expected, cultivars had different mean leaf areas (693.7, 781.2, and 796.5 $\mathrm{cm}^{2}$ for 'Sugar Baby,' 'Crimson Sweet,' and 'Charleston Gray,' respectively), but the cultivars did not significantly differ in the degree of pollutant suppression of leaf area.

All dry weight variables were affected significantly by year and cultivar (Table 1). Final biomass was generally greater in 1988 than in 1987, but this was especially true for 'Sugar Baby' plants 
Table 1. Mean squares for foliar injury ratings, leaf area, and dry weights of three watermelon cultivars exposed to $\mathrm{SO}_{2}$ and $\mathrm{O}_{3}$ in 1987 or 1988 .

\begin{tabular}{|c|c|c|c|c|c|c|c|}
\hline \multirow[b]{2}{*}{ Source ${ }^{z}$} & \multirow[b]{2}{*}{ df } & \multirow[b]{2}{*}{ Injury ${ }^{\mathrm{y}, \mathrm{x}}$} & \multirow[b]{2}{*}{ Leaf area ${ }^{\mathrm{x}, \mathrm{w}}$} & \multicolumn{4}{|c|}{ Dry wt (g) } \\
\hline & & & & Top $^{x}$ & $\operatorname{Root}^{x}$ & Total $^{\mathrm{x}}$ & Root : top ${ }^{v}$ \\
\hline Year (Y) & 1 & 19.2 & 652.9 & $15.5^{*}$ & $299.4^{* * *}$ & $30.0^{*}$ & $122.09^{* * *}$ \\
\hline Blk (Y) & 2 & 12.5 & 61.8 & 0.5 & 3.4 & 0.7 & 0.31 \\
\hline $\mathrm{SO}_{2}$ & 4 & $24.1^{* *}$ & $7.8^{*}$ & 0.6 & 2.4 & 0.5 & $1.63^{*}$ \\
\hline SL & 1 & $90.9^{* * *}$ & $30.3^{* *}$ & & $7.8^{*}$ & & $3.66^{* * *}$ \\
\hline $\mathrm{O}_{3}$ & 1 & $292.2^{* * *}$ & $23.2^{* *}$ & $9.4^{*}$ & $8.0^{*}$ & $10.3^{*}$ & 1.00 \\
\hline $\mathrm{SO}_{2} \times \mathrm{O}_{3}$ & 4 & $24.1^{* *}$ & 3.5 & 4.8 & 1.5 & 4.7 & 0.47 \\
\hline $\mathrm{SL} \times \mathrm{O}_{3}$ & 1 & $90.9^{* *}$ & $12.7^{*}$ & $15.5^{* *}$ & & $15.5^{* *}$ & \\
\hline $\mathrm{SO}_{2} \times \mathrm{Y}$ & 4 & 0.9 & 0.3 & 1.7 & 1.7 & 1.7 & 0.53 \\
\hline $\mathrm{O}_{3} \times \mathrm{Y}$ & 1 & 19.2 & 1.4 & 2.4 & 0.1 & 2.3 & 0.04 \\
\hline $\mathrm{SO}_{2} \times \mathrm{O}_{3} \times \mathrm{Y}$ & 4 & 0.9 & 1.6 & 0.2 & 0.9 & 0.3 & 0.53 \\
\hline $\mathrm{Cov}_{\mathrm{a}}$ & 1 & & & 7.6 & $6.9^{*}$ & $8.5^{*}$ & \\
\hline Error & $17,18^{\mathrm{u}}$ & 5.3 & 2.3 & 1.9 & 1.4 & 1.9 & 0.43 \\
\hline Cultivar (C) & 2 & $13.7^{* *}$ & $70.2^{* * *}$ & $21.3^{* *}$ & $69.1^{* * *}$ & $25.3^{* *}$ & $44.02^{* *}$ \\
\hline CG\&CS vs. SB & 1 & $17.4^{* *}$ & $137.6^{* *}$ & $4.2^{*}$ & $103.3^{* * *}$ & $9.0^{* *}$ & $79.41^{* *}$ \\
\hline CG vs. CS & 1 & $10.0^{* *}$ & & $42.5^{* *}$ & $72.7^{* *}$ & $49.4^{* *}$ & $8.63^{* *}$ \\
\hline $\mathrm{SO}_{2} \times \mathrm{C}$ & 8 & 2.1 & 0.9 & 0.7 & 1.1 & 0.7 & 0.33 \\
\hline $\mathrm{SL} \times \mathrm{CG} \& \mathrm{CS}$ vs. SB & 1 & $14.6^{* *}$ & & & & & \\
\hline $\mathrm{O}_{3} \times \mathrm{C}$ & 2 & $13.7^{* *}$ & 1.4 & 0.8 & 1.0 & 0.9 & 0.07 \\
\hline $\mathrm{O}_{3} \times \mathrm{CG} \& \mathrm{CS}$ vs. SB & 1 & $17.4^{* *}$ & & & & & \\
\hline $\mathrm{O}_{3} \times \mathrm{CG}$ vs. $\mathrm{CS}$ & 1 & $10.0^{* *}$ & & & & & \\
\hline $\mathrm{SO}_{2} \times \mathrm{O}_{3} \times \mathrm{C}$ & 8 & 2.1 & 1.4 & 0.6 & 1.3 & 0.7 & 0.49 \\
\hline $\mathrm{SL}^{2} \times \mathrm{O}_{3} \times \mathrm{CG} \& \mathrm{CS}$ vs. $\mathrm{SB}$ & 1 & $14.6^{* *}$ & & & & & \\
\hline $\mathrm{C} \times \mathrm{Y}$ & 2 & 0.4 & 3.6 & $7.2^{* *}$ & 0.4 & $6.5^{* *}$ & $4.77^{* *}$ \\
\hline $\mathrm{CG} \& \mathrm{CS}$ vs. $\mathrm{SB} \times \mathrm{Y}$ & 1 & & & $8.3^{* *}$ & & $7.6^{* *}$ & $9.17^{* *}$ \\
\hline $\mathrm{SO}_{2} \times \mathrm{C} \times \mathrm{Y}$ & 8 & 1.0 & 0.7 & 0.3 & 0.6 & 0.3 & 0.32 \\
\hline $\mathrm{O}_{3} \times \mathrm{C} \times \mathrm{Y}$ & 2 & 0.4 & 0.5 & 0.9 & 1.2 & 1.1 & 0.14 \\
\hline $\mathrm{SO}_{2} \times \mathrm{O}_{3} \times \mathrm{C} \times \mathrm{Y}$ & 8 & 1.0 & 2.1 & 1.6 & 1.2 & 1.7 & 0.27 \\
\hline $\operatorname{Cov}_{b}$ & 1 & & & $17.0^{* *}$ & $9.2^{* *}$ & $17.6^{* *}$ & \\
\hline Error $_{b}$ & $39,40^{\mathrm{u}}$ & 1.0 & 1.3 & 1.0 & 0.9 & 1.0 & 0.36 \\
\hline Total & 119 & & & & & & \\
\hline
\end{tabular}

${ }^{\mathrm{z}} \mathrm{SL}=\mathrm{SO}_{2}$ linear; $\mathrm{CG}, \mathrm{CS}$, and $\mathrm{SB}=$ 'Charleston Gray,' 'Crimson Sweet' and 'Sugar Baby,' respectively.

'Data were recorded for the first five leaves as percentage of leaf area injured, and the averages of these individual leaf ratings were transformed by the arcsin of the square-root function.

${ }^{\mathrm{x}}$ Combined-experiment analyses were weighted by $1 / \mathrm{s}^{2}$ from analyses by year.

weaf area $\left(\mathrm{cm}^{2}\right)$ was measured for the first seven mainstem leaves.

${ }^{\mathrm{v}}$ Mean squares have been multiplied by $10^{4}$.

"Error terms from ANOVAs have $1 \mathrm{df}$ more than error terms from ANCOVAs.

**** Significant at $0.01<P \leq 0.05$ or $P \leq 0.01$, respectively. Only significant partitions of treatment effects are given.

(Table 2). The difference in magnitude of cultivar responses between years and/or the difference in 'Sugar Baby' plant size for the 2 years resulted in year $\times$ cultivar interactions. Root dry weight, the only dry weight variable for which no cultivar $\times$ year interaction occurred, was greatest for 'Charleston Gray' and smallest for 'Sugar Baby.' The year $\times$ cultivar interaction for top dry weight was significant because 'Sugar Baby' had the greatest top weight in 1988 and the lowest weight in 1987. In turn, the total dry weight for 'Sugar Baby' was much greater in 1988 than in 1987 but was similar between the 2 years for the other two cultivars. Although the relative rankings of the cultivars were the same in both years for the root : top ratio, the ratios for 'Charleston Gray' and 'Crimson Sweet' were more similar in 1988 than in 1987. Year and cultivar effects per se were of less interest in these experiments than their potential to influence pollutant effects, and no significant interactions with pollutant treatments were found for either factor.

Root dry weight was suppressed linearly by $\mathrm{SO}_{2}$ (Fig. 3a) and slightly suppressed by $\mathrm{O}_{3}(1.11$ and $1.06 \mathrm{~g}$, respectively, for 0 and 100 $\left.\mathrm{nL} \cdot \mathrm{L}^{-1}\right)$. Ozone suppressed aboveground biomass, and suppression increased linearly with $\mathrm{SO}_{2}$ dose (Fig. 3b). The influence of $\mathrm{O}_{3}$ on top weight response to $\mathrm{SO}_{2}$ was most apparent with $\mathrm{SO}_{2}$ concentrations $>200 \mathrm{~nL} \cdot \mathrm{L}^{-1}$. The enhanced top growth in response to $\mathrm{SO}_{2}$ in the absence of $\mathrm{O}_{3}$ was equivalent to the suppression that occurred in response to $\mathrm{SO}_{2}$ in the presence of $\mathrm{O}_{3}$; thus, the main effect of $\mathrm{SO}_{2}$ on top growth was not significant. Aboveground tissue accounted for a much greater percentage of the total biomass than the belowground tissue (93\% vs. 7\%, respectively) (Table 2). Thus, pollutant effects on total dry weight (Fig. 3c) resembled those found for top dry weight. Whereas root and top dry weights were linearly suppressed by $\mathrm{SO}_{2}$ in the presence of $\mathrm{O}_{3}$, suppression of root biomass was greater than that of the top (13\% and 6\%, respectively, at $400 \mathrm{~nL} \cdot \mathrm{L}^{-1} \mathrm{SO}_{2}$ ), and $\mathrm{SO}_{2}$ did not increase root weight in the absence of $\mathrm{O}_{3}$. Thus, the root : top ratio was suppressed linearly by $\mathrm{SO}_{2}$ (Fig. 3d) with no significant $\mathrm{O}_{3}$ effect nor any significant $\mathrm{O}_{3} \times \mathrm{SO}_{2}$ interaction in the course of these experiments.

\section{Discussion}

Ideally, pollutant concentrations in controlled studies approximate those found in the ambient environments in which the crop is 


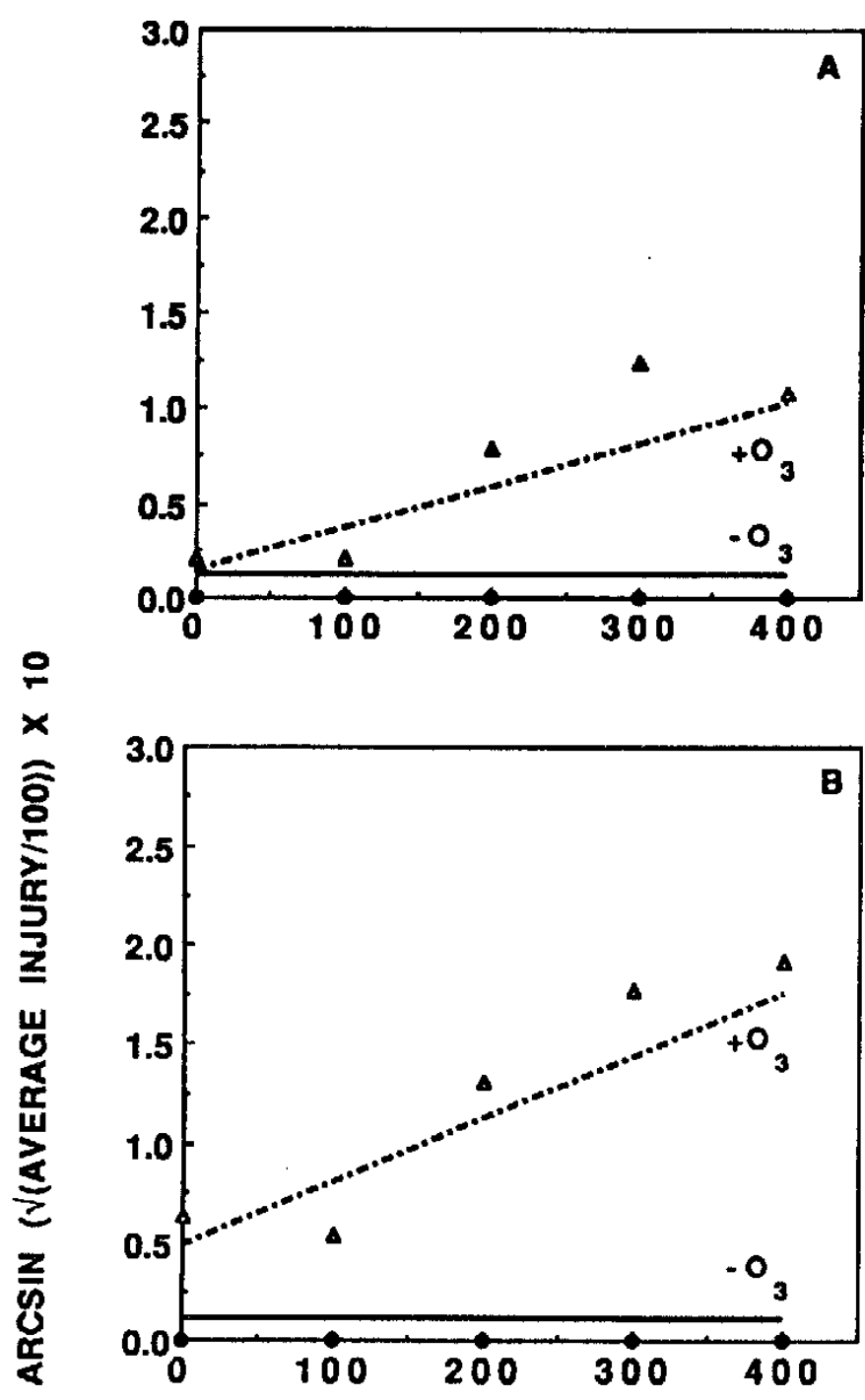

Fig. 1. Regression equations for foliar injury of three watermelon cultivars after exposure to five concentrations of $\mathrm{SO}_{2}$ in the absence or presence $\left(100 \mathrm{~nL} \cdot \mathrm{L}^{-1}\right)$ of $\mathrm{O}_{3}$. Standard errors for the parameter estimates are listed in parentheses after each estimate. Injury ratings were based on the average (leaves 1-5) percentage of leaf surface injured by pollutants. Injury ratings were transformed with the arcsin of the square root function prior to analysis, and the regression analysis was weighted by $1 / \mathrm{s}^{2}$ from the individual analyses by year. (A) 'Charleston Gray': Transformed average injury $=0.0116415-0.000000(0.0000666) \mathrm{SO}_{2}+0.0000269$ (0.0002308) $\mathrm{O}_{3}+0.00000221(0.00000094) \mathrm{SO}_{2} \times \mathrm{O}_{3}$. (B) 'Crimson Sweet': Transformed average injury $=0.011317-0.000000(0.0000666) \mathrm{SO}_{2}+0.0003689$ (0.0002308) $\mathrm{O}_{3}+0.00000318(0.00000094) \mathrm{SO}_{2} \times \mathrm{O}_{3}$. (C) 'Sugar Baby': Transformed average injury $=0.006969-0.000000(0.0000666) \mathrm{SO}_{2}+0.0000439$ (0.0002308) $\mathrm{O}_{3}+0.00000695(0.00000094) \mathrm{SO}_{2} \times \mathrm{O}_{3}$.

grown. Ambient hourly $\mathrm{O}_{3}$ concentrations have been reported for the melon-growing seasons in Vincennes, Ind., in 1984 and 1985 (Decoteau et al., 1986; Simini et al., 1989; Simon et al., 1986) and for Decker, Ind., in 1986 and 1987 (Snyder et al., 1988). These hourly averages include data from overcast or rain days when $\mathrm{O}_{3}$ concentrations are naturally lower. In all 4 years, the hourly averages over the growing seasons peaked between 55 and 70 $\mathrm{nL} \cdot \mathrm{L}^{-1}$, with concentrations fluctuating around the peak for 5 to 8 h. In our experiments, square wave exposures were restricted to 4 h/day and only 5 days/week. Therefore, we chose to exceed the ambient hourly $\mathrm{O}_{3}$ average in Indiana without exceeding the U.S. national ambient air quality standard of $120 \mathrm{~nL} \cdot \mathrm{L}^{-1}$ maximum hourly average $\mathrm{O}_{3}$ concentration.

Ambient $\mathrm{SO}_{2}$ levels near point sources are generally more variable throughout the day than ambient $\mathrm{O}_{3}$ levels, which follow a diurnal pattern. In addition, $\mathrm{SO}_{2}$ levels are occasionally elevated during darkness. Simon et al. (1986) monitored $\mathrm{SO}_{2}$ levels at a Decker site, which was selected to receive maximum $\mathrm{SO}_{2}$ exposures from local point sources. They found higher $\mathrm{SO}_{2}$ levels during the hours when $\mathrm{O}_{3}$ concentrations are generally high. For example, in 1984, elevated $\mathrm{SO}_{2}$ levels were recorded as often as 39,
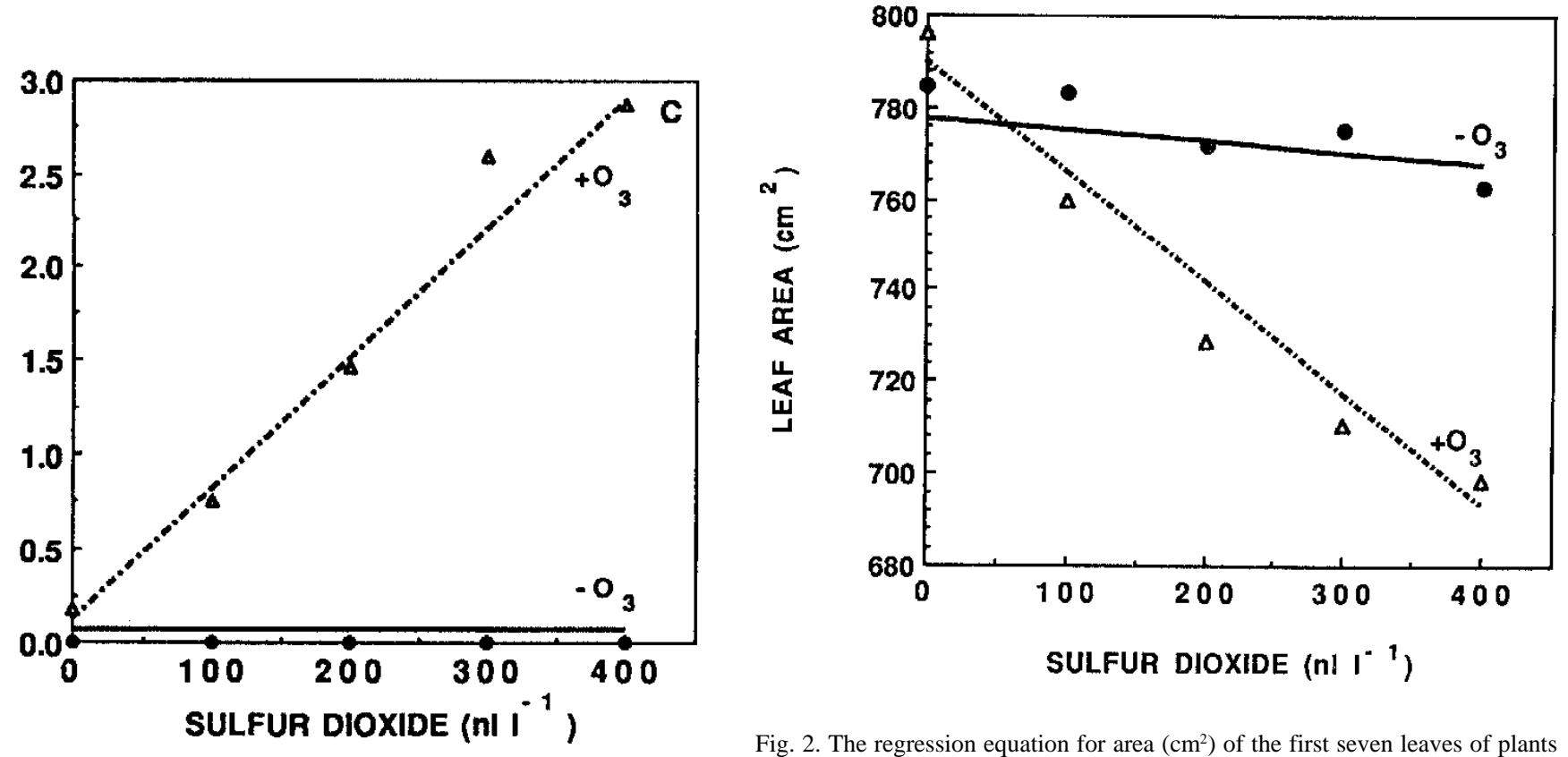

Fig. 2. The regression equation for area $\left(\mathrm{cm}^{2}\right)$ of the first seven leaves of plants exposed for 22 days to five concentrations of $\mathrm{SO}_{2}$ in the absence or presence $(100$ $\left.\mathrm{nL} \cdot \mathrm{L}^{-1}\right)$ of $\mathrm{O}_{3}$. Standard errors for the parameter estimates are listed in parentheses after each estimate. Regression analysis was weighted by $1 / \mathrm{s}^{2}$ from the individual analyses by year. Leaf area $=777.763-0.0256(0.0454) \mathrm{SO}_{2}+0.1238(0.1574)$ $\mathrm{O}_{3}-0.00217(0.00064) \mathrm{SO}_{2} \times \mathrm{O}_{3}$. 
Table 2. Adjusted dry weight means ${ }^{\mathrm{z}}$ with standard errors by year and watermelon cultivar.

\begin{tabular}{llllll}
\hline \hline & & \multicolumn{3}{c}{ Dry wt $(\mathrm{g})$} \\
\cline { 3 - 6 } Year & Cultivar & Top & Root & Total & Root:top $^{\mathrm{y}}$ \\
\hline 1987 & Charleston Gray & $14.6(0.1)$ & $1.1(0.1)$ & $15.7(0.1)$ & $7.8(0.02)$ \\
& Crimson Sweet & $13.0(0.1)$ & $0.9(0.1)$ & $13.9(0.1)$ & $7.0(0.02)$ \\
& Sugar Baby & $11.9(0.1)$ & $0.7(0.1)$ & $12.6(0.1)$ & $6.2(0.02)$ \\
1988 & Charleston Gray & $14.2(0.1)$ & $1.4(0.1)$ & $15.6(0.1)$ & $10.0(0.02)$ \\
& Crimson Sweet & $12.9(0.1)$ & $1.2(0.1)$ & $14.1(0.1)$ & $9.5(0.02)$ \\
& Sugar Baby & $14.4(0.1)$ & $1.1(0.1)$ & $15.5(0.1)$ & $7.5(0.02)$
\end{tabular}

${ }^{\bar{z}}$ Means have been adjusted for the covariate (where applicable). The 1987 experiment included 60 'Charleston Gray’ plants. All other year and cultivar combinations included 80 plants.

y Ratio values and standard errors should be multiplied by $10^{-2}$ and $10^{-4}$, respectively.

37, and $56 \mathrm{~h}$ in June, July, and August, respectively. Similar data were recorded for 1985. During these periods, hourly averages exceeded $100 \mathrm{~nL} \cdot \mathrm{L}^{-1}$ and instantaneous peaks exceeded $500 \mathrm{~nL} \cdot \mathrm{L}^{-1}$ $\mathrm{SO}_{2}$ (Simon, unpublished data). Our square wave exposures included $\mathrm{SO}_{2}$ levels much higher than ambient hourly averages in Indiana. However, incorporating treatment levels beyond the ambient concentration improves the efficiency of dose response models, and higher treatment levels are not inappropriate as long as they do not distort the continuity of the response surface (Rawlings et al., 1988). Response surface models incorporating high pollutant doses have been of value in predicting vegetation response to pollutant concentrations exceeding the national standards.

Sulfur dioxide altered the phytotoxic effects of $\mathrm{O}_{3}$ on watermelon in these experiments. Ozone induced foliar injury and reduced leaf area and root, top, and total dry weights, but combined with $\mathrm{SO}_{2}$, the toxic effects of $\mathrm{O}_{3}$ were intensified. In the absence of $\mathrm{O}_{3}$, no visible injury occurred, suppression of leaf area was minimal, and top and total dry weights increased with increased $\mathrm{SO}_{2}$ concentrations. Root biomass and the root : top ratio were linearly suppressed by $\mathrm{SO}_{2}$, and for these variables the phytotoxicity of $\mathrm{SO}_{2}$ was independent of $\mathrm{O}_{3}$
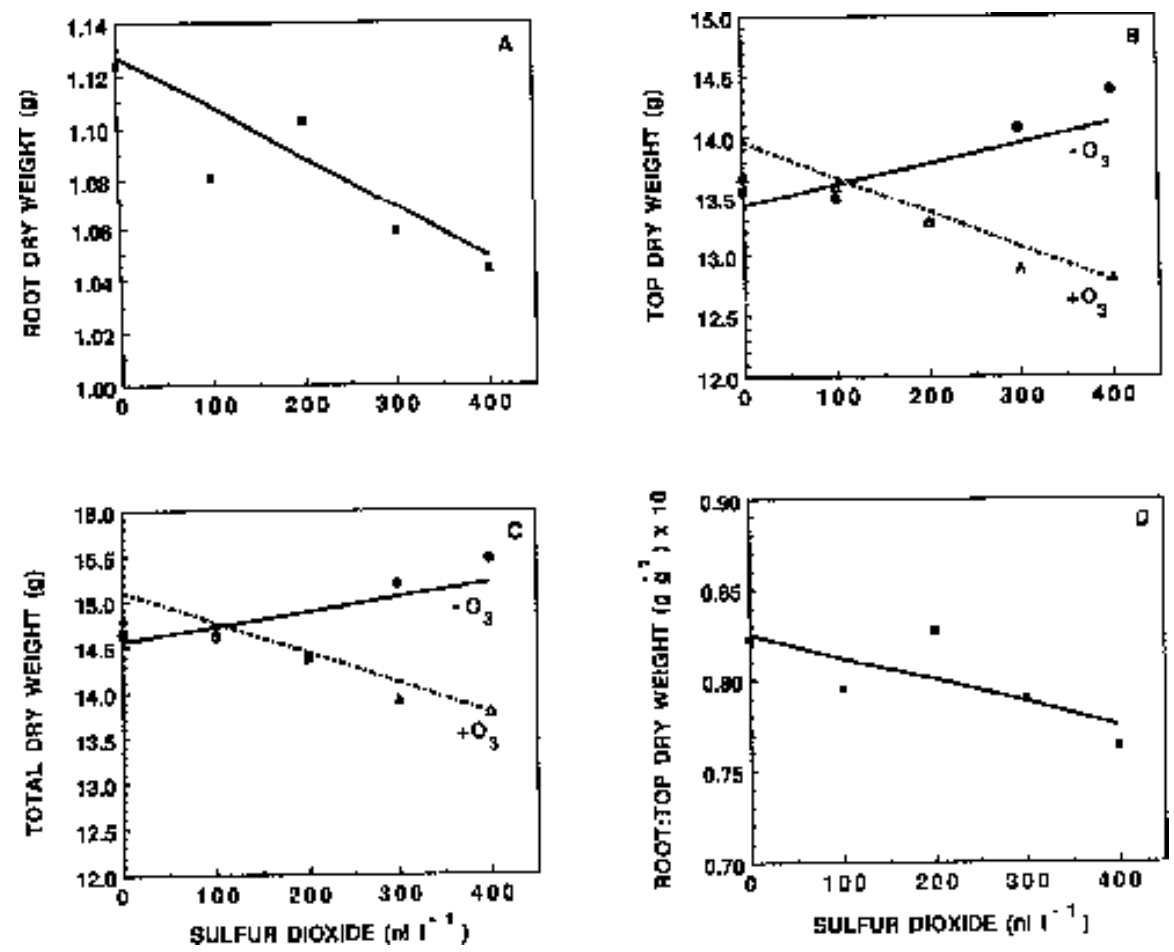

Fig. 3. Regression equations for root (A), top (B), total plant $(\mathbf{C})$, and root : top (D) dry weight $(\mathrm{g})$ responses to five concentrations of $\mathrm{SO}_{2}$ in the absence or presence $\left(100 \mathrm{~nL} \cdot \mathrm{L}^{-1}\right)$ of $\mathrm{O}_{3}$ after 22 days of exposure. Standard errors for the parameter estimates are listed in parentheses after each estimate. Analyses for root, top, and total dry weights were weighted by $1 / \mathrm{s}^{2}$ from their individual analyses by year. (A) Root dry weight $=0.076$ cov + $0.174 \operatorname{cov}_{\mathrm{b}}+1.154-0.0002(0.0001) \mathrm{SO}_{2}-0.0005$ $(0.0002) \mathrm{O}_{3}$. (B) Top dry weight $=1.072 \mathrm{cov}_{\mathrm{a}}+1.848$ $\operatorname{cov}_{\mathrm{b}}+13.427+0.0017(0.0008) \mathrm{SO}_{2}+0.0053(0.0026)$ $\mathrm{O}_{3}-0.000047(0.00001) \mathrm{SO}_{2} \times \mathrm{O}_{3} .(\mathbf{C})$ Total dry weight $=1.152 \operatorname{cov}_{\mathrm{a}}+1.985 \operatorname{cov}_{\mathrm{b}}+14.557+0.0016(0.0008)$ $\mathrm{SO}_{2}+0.0054(0.0028) \mathrm{O}_{3}-0.00005(0.00001) \mathrm{SO}_{2} \times \mathrm{O}_{3}$. (D) Root : top ratio $=0.08339-0.000012(0.000004)$ $\mathrm{SO}_{2}-0.000018(0.000011) \mathrm{O}_{3}$. 
assimilate sink caused by fruit set may contribute to $\mathrm{O}_{3}$ sensitivity differences due to earliness. If fruit set results in greater vulnerability to pollutant toxicity, then earlier cultivars would be impacted earlier in the growing season than later cultivars, and higher ambient $\mathrm{O}_{3}$ levels are more probable during the earlier part of the watermelon season in most regions of the United States. Field chamber experiments with multiple cultivars and mixtures of $\mathrm{SO}_{2}$ and $\mathrm{O}_{3}$ should address the relationships of fruit set and earliness to pollutant sensitivity. The importance of cation-exchange capacity, soil $\mathrm{pH}$, and nitrogen source have been examined for muskmelon and watermelon cultivation (Elamin and Wilcox, 1986; Simon and Wilcox, 1984; Gerald Wilcox, personal communication) and $\mathrm{SO}_{2}$ exposures (Kaiser et al., 1993; Kropff, 1991), but almost no information is available on the relationship of these factors to $\mathrm{SO}_{2}$ and $\mathrm{O}_{3}$ effects on watermelon. Such research might lead to recommendations that could be implemented by growers to ameliorate the impacts of pollutants, even though ambient concentrations of pollutants cannot be directly controlled.

\section{Literature Cited}

Beckerson, D.W. and G. Hofstra. 1979. Response of leaf diffusive resistance of radish, cucumber and soybean to $\mathrm{O}_{3}$ and $\mathrm{SO}_{2}$ singly or in combination. Atmos. Environ. 13:1263-1268.

Cooley, D. R. and W. J. Manning. 1987. The impact of ozone on assimilate partitioning in plants: A review. Environ. Pollut. 47:95-113.

Decoteau, D.R., J.E. Simon, G. Eason, and R.A. Reinert. 1986. Ozoneinduced injury on field-grown watermelons. HortScience 21:13691371.

Elamin, O.M. and G.E. Wilcox. 1986. Effect of magnesium and manganese nutrition on watermelon growth and manganese toxicity. J. Amer. Soc. Hort. Sci. 111:588-593.

Heck, W.W., A.S. Heagle, J.E. Miller, and J.O. Rawlings. 1990. A national program (NCLAN) to assess the impact of ozone on agricultural resources. In: R.L. Berglund, D.R. Lawson, and D.J. McKee (eds.). Tropospheric ozone and the environment. Intl. Spec. Conf., Air Waste Mgt. Assn., Pittsburgh.

Heck, W.W., R.B. Philbeck, and J.A. Dunning. 1978. A continuous stirred tank reactor (CSTR) system for exposing plants to gaseous air contami- nants: Principles, specifications, construction, and operation. U.S. Dept. of Agr.-Agr. Res. Serv., Ser. ARS-S-181.

Kaiser, W.M., M. Höfler, and U. Heber. 1993. Can plants exposed to $\mathrm{SO}_{2}$ excrete sulfuric acid through the roots? Physiol. Plant. 87:61-67.

Kropff, M.J. 1991. Long-term effects of $\mathrm{SO}_{2}$ on plants, $\mathrm{SO}_{2}$ metabolism and regulation of intracellular pH. Plant Soil 131:235-245.

Pantula, S.G., J.O. Rawlings, and T. Arumugham. 1989. Another look at among and within class regressions in analysis of covariance. North Carolina State Univ., Raleigh, Inst. Stat. Mimeogr. Ser. 1946.

Rawlings, J.O., V.M. Lesser, and K.A. Dassel. 1988. Statistical approaches to assessing crop losses. In: W.W. Heck, O.C. Taylor, and D.T. Tingey (eds.). Assessment of crop loss from air pollutants. Elsevier, Essex, U.K.

Reinert, R.A. 1984. Plant response to air pollutant mixtures. Annu. Rev. Phytopathol. 22:421-442.

Reinert, R.A., A.S. Heagle, and W.W. Heck. 1975. Plant responses to pollutant combinations. In: J. Brian Mudd and T. T. Kozlowski (eds.). Responses of plants to air pollution. Academic Press, New York.

Reinert, R., B. Sanchez, J.M. Salleras, V. Bermejo, M.J. Ochoa, and A. Tarruel. 1992. Ozone effects on watermelon plants at the Ebro Delta (Spain): Symptomatology. Agr. Ecosystems Environ. 38:41-49.

Simini, M., J.E. Simon, R.A. Reinert, and G. Eason. 1989. Identification of ozone-induced injury on field-grown muskmelons. HortScience 24:909-912.

Simon, J.E., M. Simini, D.R. Decoteau, W. McFee, K. Scheeringa, and J.E. Newman. 1986. Monitoring air pollution for its potential impact on agricultural crops in SW Indiana. Proc. Ind. Acad. Sci. 95:289-301.

Simon, J.E. and G. Wilcox. 1984. Low soil pH: A particular concern in sandy soils. Veg. Crops Hotline No. 143 (10 Oct.). Indiana Coop. Ext. Serv.

Snyder, R.G., J.E. Simon, R.A. Reinert, M. Simini, and W.W. Heck. 1988. Effects of air quality on foliar injury, growth, yield, and quality of muskmelon. Environ. Pollut. 53:187-196.

Snyder, R.G., J.E. Simon, R.A. Reinert, M. Simini, and G.E. Wilcox. 1991. Effects of air quality on growth, yield, and quality of watermelon. HortScience 26:1045-1047.

Weigel, H.J., G. Adaros, and H.J. Jäger. 1990. Yield responses of different crop species to long-term fumigation with sulphur dioxide in open-top chambers. Environ. Pollut. 67:15-28.

Winner, W.E. 1994. Mechanistic analysis of plant responses to air pollution. Ecol. Appl. 4(4): 651-661. 